\title{
40S Ribosomal Protein S6
}

National Cancer Institute

\section{Source}

National Cancer Institute. 40S Ribosomal Protein S6. NCI Thesaurus. Code C91352.

40 S ribosomal protein S6 (249 aa, $29 \mathrm{kDa}$ ) is encoded by the human RPS6 gene. This protein plays a role in the selection of genes for translation into mRNA. 